УДК 82-94

UDC

DOI: $10.17223 / 18572685 / 46 / 3$

\title{
ЗАБЫТЫЙ ЗОЛОТОЙ ВЕК: ЯРОСЛАВ МУДРЫЙ И РУСЬ ЯРОСЛАВА - ПЕРЕОСМЫСЛЕНИЯ XIX - НАЧАЛА XXI в.*
}

\section{Е.А. Ростовцев ${ }^{1}$, Д.А. Сосницкий ${ }^{2}$}

Санкт-Петербургский государственный университет Россия, 199034, г. Санкт-Петербург, Университетская набережная, 7/9

1E-mail: e.rostovtsev@spbu.ru

2E-mail:d.sosnitskij@spbu.ru

\section{Авторское резюме}

Память 0 Ярославе - общая и объединяющая восточнославянских наследников «Руси Ярослава» с сегодняшней различной национальной самоидентификацией (украинцев, русских, русинов, белорусов). Прослежен ход формирования основных представлений о князе Ярославе Мудром в общественной мысли и историческом сознании. Авторы выявили источники, которые оказали влияние на формирование этого образа, и показали место Ярослава Мудрого в российской памяти в ряду других национальных лидеров. Для осуществления этой задачи были рассмотрены наиболее массовые источники формирования памяти о прошлом, в которых упоминается имя Ярослава: учебные тексты, художественная литература, периодическая печать и публицистические произведения, кинофильмы, монументальная скульптура, специальные исторические исследования. Показан механизм влияния социального и политического заказа на формирование представлений общества о князе, дан аналитический прогноз относительно перспективы дальнейшего конструирования этого образа в массовом сознании.

Ключевые слова: Ярослав Мудрый, историческая память, историческое сознание.

\footnotetext{
* Статья подготовлена при поддержке РНФ, проект «"Мобилизованное средневековье": обращение к средневековым образам в дискурсах национального и государственного строительства в России и странах Центрально-Восточной Европы и Балкан в новое и новейшее время», № 16-18-10080.
} 


\title{
THE FORGOTTEN GOLDEN AGE: YAROSLAV THE WISE AND “YAROSLAV'S RUS" - RETHINKING IN THE 19TH - 20TH CENTURIES*
}

\author{
E.A. Rostovtsev ${ }^{1}$, D.A. Sosnitsky ${ }^{2}$ \\ Saint Petersburg State University \\ 7/9 Universitetskaya Emb., Saint Petersburg, 199034, Russia \\ ${ }^{1}$ E-mail: e.rostovtsev@spbu.ru \\ E-mail:d.sosnitskij@spbu.ru
}

\section{Abstract}

Although nowadays Ukrainians, Russians, Rusins, and Belarusians have different national self-identification, the memory about Yaroslav the Wise is what unites the East Slavic heirs of "Yaroslav's Rus". The article retraces the formation of the basic narratives about Prince Yaroslav the Wise in Russian public opinion and historical consciousness. The authors have brought out the sources that influenced the formation of Prince Yaroslav's image and shown his position in the Russian collective memory among other national leaders. This objective required the analysis of the most mass sources of memory formation referring to Yaroslav the Wise, including educational texts, fiction, periodicals, essays, films, monumental sculpture, and special historical researches. The article shows how the social and political mandate influenced the formation of public opinion about Prince Yaroslav and gives the analytical forecast concerning the prospects for the further construction of the image in the public mind.

Keywords: Yaroslav the Wise, historical memory, historical consciousness.

В нашем сознании основные представления о великом князе Киевском Ярославе I Мудром (1019-1054) связаны с текстами, формировавшимися либо в его время, либо в ближайшее столетие после его кончины («Слово о законе и благодати», «Сказание о Борисе и Глебе», «Повесть временных лет»). Это образ победителя Святополка Окаянного, создателя «Русской правды», объединителя земель, строителя храмов Святой Софии в Киеве и Новгороде, князя, завоевавшего огромный международный авторитет, родоначальника новой государственной идеологии и т. п. (см., напр.: Данилевский, Мельникова 2008). Тем не менее между канонизацией Бориса и Глеба и их брата

\footnotetext{
* This article was supported by the Russian Science Foundation, the project «"Mobilized Middle Ages" : appealing to medieval images in discourses of nation-building and statebuilding in Russia and the Central-Eastern Europe and Balkan countries in Modern and Contemporary time», $\mathrm{Nr}$ 16-18-10080.
} 
Ярослава прошла почти тысяча лет. Возникает естественный вопрос: в чем причина такой задержки? Задача настоящей статьи - попытаться реконструировать природу наших представлений об этом государственном деятеле, занимавшем тысячу лет назад не последнее место на авансцене российской и европейской истории.

\section{Общерусский миф и трудная судьба героя}

Сразу после смерти героя формируется миф о «Руси Ярослава», нашедший отражение в традициях русского летописания XII - начала XIII в. (Котляр 2008). Масштаб деяний князя соответствовал этому образу, прочно закрепленному в местах памяти - двух городах, отстоящих друг от друга в разных концах «Руси Ярослава» и названных в его честь - Ярослав (будущая Галицко-Волынская Русь) и Ярославль (будущее Владимиро-Суздальское княжество). Показательно, что и термин «русин» встречается в первой же статье «Русской правды» Ярослава. С XIX в. в отечественной исторической науке развернулась масштабная дискуссия о том, какую же этническую группу он обозначает (Правда русская 1947: 32 -42). Например, П.Н. Мрочек-Дроздовский придерживался мнения, что во времена Ярослава «понимали это название скорее в общем, нежели в частном смысле», а «в видовом смысле Русь (русин) означала варягов - руссов, дружину княжескую, в отличие от словен, полян и т. д.». В несколько ином смысле понимали значение термина Н.И. Ланге (русины как жители Южной Руси), Н.А. Максимейко (русины - киявляне). Эта тема поднимается на страницах работ советской и современной историографии. Так или иначе память о Ярославе - общая и объединяющая восточнославянских наследников «Руси Ярослава» с сегодняшней различной национальной самоидентификацией (украинцев, русских, русинов, белорусов).

Несмотря на это, значение фигуры Ярослава в формировании исторической памяти послемонгольского времени сравнительно скромное. Свою роль, конечно, сыграл сам факт обособления русских земель и начала с XIV в. процесса нового политогенеза в них. Показательно, что в наиболее важных для формирования исторического сознания памятниках Московской Руси («Степенная книга», «Синопсис») ряда черт привычного нам образа Ярослава мы не находим. «Степенная книга», повествуя о правлении князя, прямо проводит параллель между «семенем» Авраама и «семенем» Василия. В ней «богомудрый Ярослав Георгий» предстает не только как продолжатель дела отца, но и как родоначальник традиции русской церковной книжности и книжного учения, основатель Юрьева (заслуга весьма актуальная в эпоху создания памятника) и борец с язычниками, однако ни рассуждений о «Русской правде», ни о равенстве князя с императорами, ни 
о его роли как царя речи не идет (Книга Степенная 1913: 168-172). «Синопсис» - наиболее важный для русского сознания памятник переломного периода рубежа XVII-XVIII вв. - отводит Ярославу I менее двух страниц,так же в качестве заслуг указывая прежде всего строительство церквей и победы над печенегами (Синопсис 1823: 62 -63). Тенденция замалчивания заслуг Ярослава только усиливается в другом ключевом «массовом» тексте середины XVIII в. - «Кратком российском летописце» М.В. Ломоносова. Здесь подчеркивается, что Ярослав Владимирович воевал против Византии и поставил митрополита Илариона без согласия Константинополя, а также отмечается, что «новгородцам пожаловал вольные грамоты и тем к разделению России дал немалый повод» (Ломоносов 1760: 4-5).

Открытие Ярослава как законодателя принадлежит только В.Н. Татищеву (1738), впервые же «Русская правда» была издана А. Шлецером (1767) (Щапов 1984), а утверждение памятника в массовом историческом сознании произошло уже в XIX в. благодаря «Истории государства Российского» Н.М. Карамзина, который дал ее изложение в одной из глав этого сверхпопулярного сочинения, как известно, «открывшего» современникам древнюю Россию. Именно Карамзину, кстати, и приписывают прибавление к имени великого князя приставки «Мудрый». Представления же о Ярославе I как о зачинателе идеологии русского государства относятся к еще более позднему времени. Первая публикация «Слова о законе и благодати» появилась только в 1844 г. (Памятники 1844), правда, его популяризация быстро началась уже в 1850-е гг. с включением «Слова» в гимназическую программу (Программы 1853: 3). Отметим, что, несмотря на однозначно положительный образ, Ярослав не удостоился чести быть помещенным на средний ярус памятника «Тысячелетие России», открытого в 1862 г., хотя и оказался на нижнем ярусе в числе 26 фигур наиболее видных государственных деятелей.

Окончательное закрепление в массовом сознании за князем прозвища «Мудрый» относится только к последней трети XIX - началу XX в., к периоду интенсивного развития школьного образования, благодаря известным учебным текстам И.И. Беллярминова, С.Ф. Платонова и др. (Беллярминов 1871: 99-10; Платонов 1909: 42 -44). Любопытно, что в научных текстах ведущих российских ученых второй половины XIX в. (С.М. Соловьев, К.Н. Бестужев-Рюмин, В.О. Ключевский) этот пропагандистский штамп еще не встречается. Постепенный рост популяризации образа князя Ярослава Владимировича органично отражал общий тренд государственной исторической политики в дореволюционной России, в рамках которой активно эксплуатировались (и конструировались) объекты 
исторической памяти домонгольской Руси (Сосницкий 2010). К 1917 г. уже вполне сформировался современный образ князя. Малый энциклопедический словарь Брокгауза и Ефрона (1909), пожалуй, самое массовое и читаемое справочное издание начала XX в., дает почти завершенную формулу: «Ярослав I Мудрый (Георгий, Юрий), сын Владимира Святого и Рогнеды, вел. кн. Киевский 978-1054; с 1015 долго боролся с Святополком Окаянным и Мстиславом Тмутараканским; в 1036 сделался единоличным правителем Руси; разбил печенегов; издал церковный устав и «Русскую Правду»; в 1051, собрав епископов, поставил митрополита Илариона, впервые без участия константинопольского патриарха; находился в родственных отношениях с европейскими дворами; перед смертью поделил Русь на уделы между сыновьями» (Ярослав 1909).

Между тем современные исследования показывают, что в рейтинге объектов исторической памяти российского общества второй половины XIX-XX в. Ярослав I находился далеко на периферии, занимая даже среди объектов допетровской Руси 9-11-ю позицию, пропустив перед собой не только отца-крестителя, но и таких популярных персонажей, как Александр Невский, Иван Грозный, Борис Годунов. Причина этого заключалась как в том, что Ярослав I сравнительно поздно вошел в круг избранных героев русской истории и уступал соперникам по репрезентации своего образа в художественной литературе и других источниках формирования исторической памяти (Сосницкий 2015: 63-64), так и в том, что он был лишен церковных коммемораций, которые уже несколько веков поддерживали память о таких героях домонгольского времени, как Владимир Святой и Александр Невский.

\section{Герой «золотого века»?}

Социалистическая эпоха не внесла каких-либо принципиальных новаций в образ Ярослава Мудрого. Если в раннесоветский период 1920 - начала 1930-х гг. (господство школы М.Н. Покровского) князь Ярослав I рассматривался в официальном дискурсе прежде всего как «крупный феодал и участник ожесточенной борьбы за феодальное первенство», при котором Киевская держава «укрепила влияние не только на Днепровском торговом пути, но и в отдаленных частях русской равнины», а прозвище «Мудрый» заключается в кавычки (Ярослав 1931),то с середины 1930-х ситуация, по существу, возвращается к дореволюционному шаблону. В советских учебниках практически ретранслируется образ, характерный для учебных текстов начала XX B., может быть, даже с чуть большим акцентом на усиление значения правления Ярослава для русской государственности (см., напр.: Бущик 1957: 43-44; Нечкина, Лейбенгруб 1971: 38-40). 
Основным историографическим изобретением советской эпохи, оказавшим влияние на массовое сознание и ассоциируемым с Ярославом, стал конструкт о «золотом веке» Древней Руси. Появление этого конструкта в значительной степени связано с деятельностью академика Д.С. Лихачева и его усилиями по популяризации древнерусской культуры и литературы.

Нельзя, однако, сказать, что образ Ярослава в историографии XX В. «безоблачен». В советской научной литературе появились продолжающиеся до сего времени рассуждения по поводу возможной причастности Ярослава к убийству своих братьев, прежде всего князя Бориса Владимировича. Не вдаваясь в подробности этих дискуссий, отметим, что такие споры велись на фоне негласного идеологического противостояния по поводу Древней Руси между умеренным «либералом» Д.С. Лихачёвым и «консерватором-русофилом» Б.А. Рыбаковым, что, с нашей точки зрения, нашло отражение в трактовке образа Ярослава Мудрого. Продолжая традиции другого известного историка-«русофила» - М.В. Ломоносова, Б.А. Рыбаков критически смотрит на Ярослава, отказавшегося давать урок на общегосударственные нужды и нанявшего варягов для борьбы за власть. Ученый считает, что Ярослав, начавший свою карьеру с усобицы, не оставил «благодарной памяти» в народе, а потому его имя не нашло отражения в былинном эпосе (см., напр.: Рыбаков 1982:164; Рыбаков 2003: 10). Интересно, что Рыбаков, прямо не соглашаясь с версией о Ярославе как убийце Бориса, вполне допускает ее достоверность. Однако за рамки академической трибуны в советской историографии эти спекуляции не выходили, да и в целом, несмотря на отмеченные колебания, образ Ярослава в исторической литературе оставался позитивным (см., в частности, Кучкин 1986).

Однако более важна для нашей темы все же роль Ярослава Мудрого в пространстве публичной истории. Хотя нельзя сказать, что Ярославу чрезмерно везет в источниках формирования исторической памяти, внимание к этой фигуре в советском обществе присутствовало неизменно. Пожалуй, наиболее массовым художественным текстом о персонажах допетровской истории стала драматическая поэма Ивана Кочерги «Ярослав Мудрый» (1946), изданная после войны на украинском языке и почти сразу - в авторизованном переводе на русском. Популяризация общего древнерусского героя на Украине казалась безопасной для советского режима. В драме И. Кочерги Ярослав предстает мудрым правителем, жестокость которого была вынужденной. Его речь обращена не столько к дочери Елизавете, сколько к зрителю / читателю сталинской эпохи: 
«Вот видишь, дочь, в народе мир и лад

Не насаждают кроткими руками,

Как полный зелени и солнца тихий сад.

Как дикий лес - мотыгами, плугами,

Так государство нужно корчевать,

Чтоб вырастить покой и благодать»

(Кочерга 1954: 38)

Если произведение И. Кочерги довольно настороженно рассматривает международные родовые связи Ярослава и его семьи, то по окончании периода «борьбы с космополитизмом» их художественное осмысление происходит через призму дискурса о международном признании русского государства (см., напр.: Мавродин 1974). Особенно популярна тема Анны Ярославны - королевы Франции, которой даже посвящен популярный в конце 1970-1980-х гг. советско-польский фильм с одноименным названием (1978 г., режиссёр Игорь Масленников). Сыгравший роль князя Кирилл Лавров создает фигуру сильного и мудрого правителя. В весьма позитивном ключе выдержан образ князя и в кинокартине режиссёра Григория Кохана «Ярослав Мудрый» (1981). Тем не менее нельзя не отметить, что популярные тексты и фильмы, посвященные Ярославу Владимировичу, все же численно очень ограничены, и это обстоятельство, на наш взгляд, не позволяло князю подняться в рейтинге героев исторической памяти. Отметим, что, по нашим данным, легендарному князю в СССР был воздвигнут лишь единственный памятник (Белая Церковь, 1983), если не считать мемориального знака в честь библиотеки Ярослава у Софийского собора в Киеве (1969).

С нашей точки зрения, проблема заключалась здесь не в личности самого персонажа, который воспринимался в официальном историческом дискурсе весьма положительно, а в том, что основными «местами консенсуса» и главными героями в рамках советского историко-информационного пространства были известные личности из революционного пантеона более позднего времени, в то время как Ярослав Мудрый (вместе с большинством персонажей допетровской Руси) оказывался как бы в конце очереди, будучи все-таки второстепенным персонажем для исторической политики советского режима.

\section{Князь русский или украинский?}

После краха советского строя фигуры полузабытых героев прошлого оказались востребованы постсоветским обществом, ищущим новую версию национальной истории как в России,так и на Украине. 
Отражением этого обстоятельства стало и повышенное внимание к Ярославу. Идеологический характер дискуссий о князе вполне проявился и в современных спорах о гипотетическом братоубийстве, которые не устают вести историки на страницах научной и научнопопулярной печати (см., напр.: Филист 1990; Кожинов 1994; Котляр 2000; Пелевин 2006; Боровков 2012; Демиденко 2015).

С одной стороны, в современном историографическом дискурсе Ярослав зачастую видится как «князь, выступивший против своеволия, защищая попранную свободу» (Ваняшова 2014: 18), с другой - как «небесный покровитель наемных киллеров» (Бузина 2007: 56-60). В наиболее законченном идеологическом выражении представителей российской псевдопатриотической историографии схема представляется таким образом: Ярослав - западник, проводивший в жизнь «идеи меркантилизма, приоритета материальных ценностей над духовными», который противопоставляется своему высокодуховному отцу-патриоту, исповедовавшему истинное византийское христианство,-Владимиру (Ассонов 2015).

Несомненно, что для образа князя куда важнее другие источники формирования исторического сознания. Так, в постсоветских учебниках дается одинаково позитивная картина правления Ярослава Владимировича. Авторы подчеркивают, что князь был грамотным политиком и удачливым воином. Вот как, например, описывается эпизод осады Киева печенегами в учебнике Н.С. Борисова, рекомендованном Министерством образования и неоднократно переиздававшимся: «В жестоком сражении под стенами Киева печенеги были наголову разбиты. Ярослав еще раз доказал современникам, что мудрость и доблесть - родные сестры» (Борисов 2009: 39-40). В учебнике для 10-го класса средних школ О.Н. Журавлевой дана характеристика правления Ярослава как «золотого века» древнерусской истории (Журавлева 2013: 38-40).

В современных художественных текстах Ярослав Мудрый - нечастый гость, однако нельзя сказать, что его фигура совсем обделена вниманием авторов. В популярной беллетристической литературе этот киевский князь часто встречается в произведениях Б. Акунина (он же А. Брусникин). В них создан образ исключительно прозорливого государственного деятеля, который смог создать прочную систему управления государством: «Прежняя Русь, Третий Рим и Второй Царьград, по-прежнему стояла на фундаменте, заложенном Владимиром Красно Солнышко и Ярославом Мудрым» (Брусникин 2008: 95); «Их прогнал мудрый Ярослав, великий прапрапрадед, и после этого целых тридцать лет Русь жила спокойно, не ожидая с востока напасти. Про те блаженные, сытые годы можно прочесть в летописях, но верилось с 
трудом: как это возможно, чтобы за Смерть-рекой не ходили грозовые тучи, не рокотали громы, не посверкивали молнии?» (Акунин 2014: 360). Кроме того, Ярослав Мудрый стал главным героем произведений В.Н. Есенкова (Есенков 2007), В.А. Замыслова (Замыслов 2004), П.А. Загребельного (Загребельный 2015) и др.

Отличительной чертой статей о Ярославе Мудром в онлайн-энциклопедиях (таких как «Википедия», «Кругосвет», «Кирилл и Мефодий» и др.) является то, что в них, в отличие от школьных учебников, дано подробное описание эпизода борьбы за киевский престол Ярослава со своим отцом Владимиром Святым и братьями. Эти данные позволяют более критически взглянуть на личность князя, однако в целом его образ в интернет-ресурсах также позитивен. Нельзя не упомянуть и про популяризацию Ярослава Мудрого посредством кино и музыки. Так, в 2010 г., к 1 000-летию основания города Ярославля, на экраны вышел фильм «Ярослав. Тысячу лет назад», повествующий о событиях его ростовского княжения. А в 2002 г. в Московской консерватории состоялась премьера кантаты А. Розенблата «ярослав Мудрый».

Таким образом, можно без преувеличения констатировать, что для обывателя Ярослав Мудрый остается несомненным местом позитивного консенсуса. Политические элиты постсоветских России и Украины чувствуют это с начала 1990-х гг. 23 октября 1993 г. в Ярославле президентом России Б.Н. Ельциным был открыт памятник Ярославу Мудрому. В 1997 г. в Киеве также был установлен монумент великому князю Ярославу Владимировичу. Любопытная деталь: в российской версии памятника в одной руке князь держит макет Ярославского кремля, в украинской - Киевской Софии. На Украине «Орден князя Ярослава Мудрого» (Закон Украины) с 1995 г. (момента учреждения) до 1998 г. являлся высшей государственной наградой. 23 декабря 2014 г. Ярославской областной думой был принят закон «О праздниках и памятных датах Ярославской области», согласно которому установлен День памяти князя Ярослава Мудрого 5 марта (Закон).

Среди других примеров соперничества России и Украины за память о Ярославе Мудром - использование образа князя на денежных купюрах. Так, уже в 1992 г. на Украине появилась банкнота достоинством в 2 гривны с изображением Ярослава Мудрого (также была выпущена монета с его изображением). В России самая крупная на тот момент (2001 г.) купюра стоимостью в 1000 рублей изображала памятник князю в Ярославле. Практически одновременно, в 1995 г., два вуза России и Украины были переименованы в честь Ярослава Мудрого. Бывший Новгородский сельскохозяйственный институт (с 30 июня 1993 г. - Новгородский государственный университет) 
19 января 1995 г. получил название «Новгородский государственный университет имени Ярослава Мудрого» (Названия); 4 ноября 1995 г. Украинская государственная юридическая академия имени Дзержинского обрела новое имя - «Национальная юридическая академия Украины имени Ярослава Мудрого» (Об университете). С 2009 г. в составе Балтийского флота ВМФ России находится сторожевой корабль «Ярослав Мудрый».

Это своеобразное соперничество активно продолжается на церковном уровне. Ярослав Мудрый в 2004 г. был внесен в месяцеслов Украинской православной церкви Московского патриархата, а в 2005 г. Русской православной церковью был определен день его памяти 20 февраля. На Поместном соборе 2008 г. Украинской православной церкви Киевского патриархата Ярослав Мудрый был канонизирован как святой благоверный князь. Согласно определению Освященного архиерейского собора РПЦ об общецерковном прославлении ряда местночтимых святых от 2-3 февраля 2016 г., святой благоверный князь Ярослав Мудрый получил общецерковное почитание (Определение). Таким образом, борьба за память о князе, наконец, приобщила героя к лику святых.

В завершение темы сходства российской и украинской государственных стратегий по популяризации образа великого князя нельзя не сказать о телевизионном проекте «Великие украинцы», транслировавшемся на одном из центральных украинских телеканалов в 2007-2008 гг. Победителем этого проекта стал именно Ярослав Мудрый (Великие украинцы). Интересно, что в России он оказался лишь на 38-й позиции в общем рейтинге (Результаты). Серьезное «отставание» наблюдается и в частоте упоминания имени Ярослава Мудрого в названиях городских объектов. Если в России они носят единичный характер (например, улица в городе Белебей, Республика Башкортостан),то на Украине улицы и площади имени великого князя встречаются во многих городах и селах (Черновцы, Мостиска и др.). Интересным источником, позволяющим сделать выводы о месте Ярослава Мудрого в массовом историческом сознании, служат социологические опросы. Проведенное нами социологическое исследование, направленное на выявление событий и явлений первостепенной важности в национальной памяти,дало следующие результаты:лишь 3,5 \% опрошенных отнесли Ярослава к числу наиболее значимых деятелей отечественной истории - это девятый результат среди всех допетровских персонажей.

Таким образом, Ярослав Мудрый, несмотря на очевидную политику популяризации образа,так и не стал пока значимым объектом памяти в постсоветской России. Иначе говоря, если на Украине Ярослав Му- 
дрый является одним из национальных исторических лидеров, то в России он скорее герой второго плана. Однако причина этого, на наш взгляд, заключается не в спорности героя для российского сознания, а в различиях в самих героических пантеонах России и Украины, у которой просто нет после Ярослава столь впечатляющего ряда правителей. Очевидно, что в российском рейтинге «государственник» Ярослав проигрывает своему отцу-крестителю именно потому, что ему приходится конкурировать с такими государственными лидерами, как Александр Невский, Иван Грозный, Иван Великий. Однако это обстоятельство вовсе не означает, что фигура Ярослава не имеет большого потенциала для последующей популяризации в российском обществе, тем более в новых условиях необходимости постоянной борьбы за него с украинскими оппонентами.

Подведем итоги. Современные черты миф о Ярославе I Мудром, в отличие от многих других персонажей допетровской истории, приобрел сравнительно поздно - в XIX - начале XX в. С одной стороны, это обстоятельство обусловило относительную слабость позиций Ярослава Мудрого в рейтингах исторической памяти российского общества новейшего времени и его «отложенную» канонизацию. С другой стороны, это же дает основание видеть перспективудальнейшей интенсивной эксплуатации образа, основные элементы которого чрезвычайно важны для мировоззрения современного общества. Борьба за «наследство» Ярослава и память о нем между «элитами» современной России и Украины также обеспечивают постоянную актуализацию этой фигуры в общественном сознании. Зримым результатом данного процесса стала долгожданная канонизация Ярослава Мудрого, которая, в свою очередь, способна дать очередной импульс как новым практикам коммемораций, связанным с великим князем, так и очередному витку борьбы за право считаться его наследниками.

\section{ЛИТЕРАТУРА}

Акунин 2014 - Акунин Б. Огненный перст. М.: АСТ жанры, 2014.

Ассонов 2015 - Асонов Н.В. Владимир Святой и Ярослав Мудрый. Выбор полюса цивилизационного притяжения // Проблемный анализ и государственно-управленческое проектирование. 2015. Вып. 2. С. 119-126.

Беллярминов 1871 - Беллярминов И.И. Элементарный курс всеобщей и русской истории. СПб., 1871. 
Борисов 2009 - Борисов Н.С. История России с древнейших времен до конца XVII века. 10 класс: учеб. для общеобразовательных учреждений: базовый уровень. М.: Просвещение, 2009.

Боровков 2012 - Боровков Д.А. Тайна гибели Бориса и Глеба. М.: Вече, 2012.

Брусникин 2008 - Брусникин А. Девятный спас. М.: АСТ Астрель, 2008.

Бузина 2007 - Бузина О. Тайная история Украины-Руси. Киев: Довира, 2007.

Бущик 1957 - Бущик Л.П. История СССР. Учебник для 8 класса средней школы. Часть первая. М., 1957.

Ваняшова 2014 - Ваняшова М.Г. Ярослав Мудрый и метасюжет «свободасвоеволие» в «Слове о полку Игореве» // Ярослав Мудрый. Проблемы изучения, сохранения и интерпретации историко-культурного наследия: Сб. материалов V Междунар. науч.-практ. конф. Ярославль: Индиго, 2014. С. 16-27.

Великие Украинцы - Сайт «Великие Украинцы». URL: https://web.archive. org/web/20131016212232/http://greatukrainians.com.ua/ru (дата обращения: 19.06.2016).

Данилевский, Мельникова 2008 - Данилевский И.Н., Мельникова А.Г. От редакторов // Ярослав Мудрый и его эпоха. М., 2008. С. 6-7.

Демиденко 2015 - Демиденко Г.Г. О некоторых тайнах биографии Ярослава Мудрого // Ярослав Мудрый. Проблемы изучения, сохранения и интерпретации историко-культурного наследия: Сб. материалов VI Междунар. науч.-практ. конф. Ярославль: Индиго, 2015. С. 7-15.

Есенков 2007 - Есенков В.Н. Ярослав Мудрый князь Ростовский, Новгородский и Киевский. Ярославль: «Еще не поздно!», 2007.

Журавлева 2013 - Журавлева О.Н., Пашкова Т.И., Кузин Д.И. История России: 10 класс: учебник для учащихся общеобразовательных учреждений / Под общ. ред. чл.-кор. РАН Р.Ш. Ганелина. М.: Вентана-Граф, 2013.

Загребельный 2015 - Загребельный П.А. Ярослав Мудрый. М.: АСТ, 2015.

Закон - Сайт «Ярославская областная дума». Закон «О праздниках и памятных датах Ярославской области». URL: http://www.duma.yar.ru/service/ acts/z14088.html (дата обращения: 19.06.2016).

Закон Украины - Сайт «Верховна Рада Украіни». Закон Украіни «Про державні нагороди Украіни». URL: http://zakon1.rada.gov.ua/laws/ show/1549-14 (дата обращения: 19.06.2016).

Замыслов 2004 - Замыслов В.А. Ярослав Мудрый: историческая дилогия. Ярославль: Лия, 2004.

Книга Степенная 1913 - Книга Степенная царского родословия. Часть первая // ПСРЛ. СПб.: Типография М.А. Александрова, 1913. Т. XXI. Первая половина. С. $168-172$.

Кожинов 1994 - Кожинов В. Клевета // Родина. 1994. № 5. С. 65-68. 
Котляр 2000 - Котляр Н.Ф. Князь Окаянный? Был ли Святополк убийцей своих братьев Бориса и Глеба // Родина. 2000. № 12. С. 35-39.

Котляр 2008 - Котляр Н.Ф. Ярослав и его время в общественном сознании второй половины XI-XIII в.// Ярослав Мудрый и его эпоха. М.: Индрик, 2008. С. 202-214.

Кочерга 1954 - Кочерга И. Ярослав Мудрый // Кочерга И. Исторические драмы. М.: Сов. писатель, 1954.

Кучкин 1976 - Кучкин В.А. Ярослав Мудрый // СИЭ. 1976. Т. 16. Стб. 984-985.

Ломоносов 1760 - Ломоносов М.В. Краткий Российский летописец. СПб.: Император. Акад. наук, 1760.

Мавродин 1974 - Мавродин В.В. Киевская Русь - начальный период истории русского народа // Озерецкая Е.Л. Звенит слава в Киеве. Л.: Дет. лит., 1974. С. 150-157.

Названия - Сайт «Новгородский государственный университет имени Ярослава Мудрого». Названия университета. URL: http://www.novsu.ru/ dept/1106/i.804531/?id=939131 (дата обращения: 19.06.2016).

Нечкина, Лейбенгруб 1971 - Нечкина М.В., Лейбенгруб П.С. История СССР: Учеб. пособие для 7 класса. М.: Просвещение, 1971.

Об университете - Сайт «Национальный юридический университет имени Ярослава Мудрого». Об университете. URL: http://nlu.edu.ua/ru (дата обращения: 19.06.2016).

Определение - Сайт «Русская Православная церковь. Официальный сайт Московского Патриархата». Определение Освященного Архиерейского Собора Русской Православной Церкви об общецерковном прославлении ряда местночтимых святых. URL: http://www.patriarchia.ru/db/text/4367765. html (дата обращения: 19.06.2016).

Памятники 1844 - Памятники духовной литературы времени великого князя Ярослава I // Прибавление к творениям святых отцов в русском переводе. М., 1844. Ч. 2. С. 204-317.

Пелевин 2006 - Пелевин Ю. Борис и Глеб. Факты и метафакты // Отечественные записки. 2006. № 2 (29). С. 276-288.

Платонов 1909 - Платонов С.Ф. Учебник русской истории для средней школы. Курс систематический. СПб., 1909. Ч. 1-2.

Правда русская 1947 - Правда русская / Под ред. акад. Б.Д. Грекова. М.; Л.: Изд-во Академии наук СССР, 1947. Т. ІІ: Комментарии.

Программы 1853 - Программы русского языка на 1853-54 гг. СПб., 1853.

Результаты - Сайт «Имя Россия. Исторический выбор 2008». Результаты социологического исследования. URL: http://top50.nameofrussia.ru/doc. html?id=1647 (дата обращения: 19.06.2016).

Рыбаков 1982 - Рыбаков Б.А. Киевская Русь и русские княжества XIIXIII вв. М.: Наука, 1982. 
Рыбаков 2003 - Рыбаков Б.А. Рождение Руси. М.: АИФ Принт, 2003.

Синопсис 1823 - Синопсис, или Краткое собрание от различных летописцев о начале славянороссийского народа. Киев, 1823.

Сосницкий 2010 - Сосницкий Д.А. Историческая память о допетровской Руси в XIX - начале XXI в.: постановка проблемы и опыт исследования // Университетский историк: альманах. СПб.:Изд-во исторического факультета СПбГУ, 2010. Вып. 7. С. 423-430.

Сосницкий 2015 - Сосницкий Д.А. Историческая память о допетровской Руси в России второй половины XIX - начала XXI вв.: дис. ... канд. ист. наук. СПб.: СПбГУ, 2015.

Филист 1990 - Филист Г.М. История «преступлений» Святополка Окаянного. Минск: Беларусь, 1990.

Щапов 1984 - Щапов Я.Н. Русская правда. Введение // Российское законодательство X-XX веков. М.: Юрид. лит., 1984. Т. 1: Законодательство Древней Руси. С. 28.

Ярослав 1931 - Ярослав I Владимирович // БСЭ. М.: Большая Советская энциклопедия, 1931. T. LXV.C. 25.

Ярослав 1909 - Ярослав I Мудрый // Малый энциклопедический словарь. СПб.: Брокагуз-Ефрон, 1909. Т. ІІ, вып. ІV. Стб. 2204.

\section{REFERENCES}

Akunin, B. (2014) Ognennyy perst [The Fiery Finger]. Moscow: AST zhanry.

Asonov, N.V. (2015) Vladimir Svyatoy i Yaroslav Mudryy. Vybor polyusa tsivilizatsionnogo prityazheniya [St. Vladimir and Yaroslav the Wise. The choice of the pole of civilizational attraction]. Problemnyy analiz i gosudarstvennoupravlencheskoe proektirovanie - Problem Analysis and Public Administration Projection. 2. pp. 119-126.

Bellyarminov, I.I. (1871) Elementarnyy kurs vseobshchey i russkoy istorii [The Elementary Course of General and Russian History]. St. Petersburg: N. Neklyudov.

Borisov, N.S. (2009) Istoriya Rossii s drevneyshikh vremen do kontsa XVII veka. 10 klass [The History of Russia from Ancient Times to the Late 17th Century. 10 Grade]. Moscow: Prosveshchenie.

Borovkov, D.A. (2012) Tayna gibeli Borisa i Gleba [The Mystery of Boris and Gleb's Murder]. Moscow: Veche.

Brusnikin, A. (2008) Devyatnyy spas [The Ninth Savior]. Moscow: AST Astrel'. Buzina, O. (2007) Taynaya istoriya Ukrainy-Rossii [The secret history of UkraineRussia]. Kiev: Dovira.

Bushchik, L.P. (1957) Istoriya SSSR. Uchebnik dlya 8 klassa [History of the USSR. The textbook for Grade 8]. Moscow. Part 1. 
Vanyashova, M.G. (2014) [Yaroslav the Wise, and the "freedom - self-will" metaplot in "The Tale of Igor's Campaign"]. Yaroslav mudryy. Problemy izucheniya, sokhraneniya $i$ interpretatsii istoriko-kul'turnogo naslediya [Yaroslav the Wise: The Problem of Study, Preservation and Interpretation of the Historical and Cultural Heritage]. Proc. of the Fifth International Conference. Yaroslavl: Indigo. pp. 16-27 (In Russian).

The Official Website "The Great Ukrainians". (n.d.) [Online] Available from: https://web.archive.org/web/20131016212232/http://greatukrainians.com. ua/ru (Accessed: 19th June 2016).

Danilevsky, I.N. \& Melnikova, A.G. (2008) Ot redaktorov [Editorial]. In: Danilevsky, I.N. \& Melnikova, A.G. (eds) Yaroslav Mudryy i ego epokha [Yaroslav the Wise and his era]. Moscow: Indrik. pp. 6-7.

Demidenko, G.G. (2015) [On some mysteries of Yaroslav the Wise's biography]. Yaroslav mudryy. Problemy izucheniya, sokhraneniya i interpretatsii istorikokul'turnogo naslediya [Yaroslav the Wise: The Problem of Study, Preservation and Interpretation of the Historical and Cultural Heritage]. Proc. of the Sixth International Conference. Yaroslavl: Indigo. pp. 7-15 (In Russian).

Esenkov, V.N. (2007) Yaroslav Mudryy knyaz'Rostovskiy, Novgorodskiy i Kievskiy [Yaroslav the Wise, Prince of Rostov, Novgorod and Kiev]. Yaroslavl: Eshche ne pozdno!

Zhuravleva, O.N., Pashkova, T.I. \& Kuzin, D.I. (2013) Istoriya Rossii: 10 klass [History of Russia: Grade 10]. Moscow: Ventana-Graf.

Zagrebelnyy, P.A. (2015) Yaroslav Mudryy [Yaroslav the Wise]. Moscow: AST.

The Yaroslavl Regional Duma Official Website. (n.d.) Zakon "O prazdnikakh i pamyatnykh datakh Yaroslavskoy oblasti" [Law "On holidays and memorable dates in Yaroslavl Region"]. [Online] Available from: http://www.duma.yar.ru/ service/acts/z14088.html (Accessed: 19th June 2016).

The Verkhovna Rada of Ukraine (Ukrainian parliament). (n.d.) Sayt "Zakon Ukraini". Pro derzhavni nagorodi Ukraini [The Website "The Law of Ukraine". About Ukrainian state awards]. [Online] Available from: http://zakon1.rada. gov.ua/laws/show/1549-14 (Accessed: 19th June 2016).

Zamyslov, V.A. (2004) Yaroslav Mudryy: istoricheskaya dilogiya [Yaroslav the Wise: A historical duology]. Yaroslavl: Liya.

Anon. (1913) Kniga Stepennaya tsarskogo rodosloviya. Chast' pervaya (1913) [The Book of Degrees of the Royal Genealogy]. In: Vasenko, P.G. (ed.) Polnoye Sobraniye russkikh letopisey [The Complete Collection of Russian Chronicles]. Vol. 21 (1). St. Petersburg: M.A. Aleksandrov. pp. 168-172.

Kozhinov, V. (1994) Kleveta [Slander]. Rodina. 5. pp. 65-68.

Kotlyar, N.F. (2000) Knyaz' Okayannyy? Byl li Svyatopolk ubiytsey svoikh brat'ev Borisa i Gleba [The Prince Cursed? Whether Svyatopolk killed his brothers Boris and Gleb]. Rodina. 12. pp. 35-39. 
Kotlyar, N.F. (2008) Yaroslav i ego vremya v obshchestvennom soznanii vtoroy poloviny XI - XIII v. [Yaroslav and his era in the public consciousness of the late 11th - early 13th centuries]. In: Danilevsky, I.N. \& Melnikova,A.G. (eds) Yaroslav Mudryy i ego epokha [Yaroslav the Wise and his era]. Moscow: Indrik. pp. 202-214.

Kocherga, I. (1954) Istoricheskie dramy [The History Dramas]. Moscow: Sovetskiy pisatel'.

Kuchkin, V.A. (1976) Yaroslav Mudryy [Yaroslav the Wise]. In: Zhukov, E.M. et al. (eds) Sovetskaya istoricheskaya entsiklopediya [Soviet Historical Encyclopedia]. Vol. 16. Moscow: Sovetskaya entsiklopediya. pp. 984-985.

Lomonosov, M.V. (1760) Kratkiy Rossiyskiy letopisets [The Brief Russian Chronicle]. St. Petersburg: Imperial Academy of Sciences.

Mavrodin, V.V. (1974) Kievskaya Rus' - nachal'nyy period istorii russkogo naroda [Kievan Rus - the initial period of the history of Russian people]. In: Ozeretskaya, E.L. (ed.) Zvenit slava v Kieve [The Ringing Glory in Kiev]. Leningrad: Detskaya literatura. pp. 150-157.

Novgorod State University Official Website.(n.d.) Sayt "Novgorodskiy gosudarstvennyy universitet imeni Yaroslava Mudrogo". Nazvaniya universiteta [Novgorod State University named after Yaroslav the Wise. The Name of the University]. [Online] Available from: http://www.novsu.ru/dept/1106/i.804531/?id=939131 (Accessed: 19th June 2016).

Nechkina, M.V. \& Leybengrub, P.S. (1971) Istoriya SSSR. Uchebnoe posobie dlya 7 klassa [History of the USSR. Textbook for Grade 7]. Moscow: Prosveshchenie.

National Law University named after Yaroslav the Wise Official Website.(n.d.) Natsional'nyy yuridicheskiy universitet imeni Yaroslava Mudrogo. Ob universitete [National Law University named after Yaroslav the Wise. On the University]. [Online] Available from: http://nlu.edu.ua/ru/\%D0\%BF\%D1\%80\%D0\%BE-\%D1 \%83\%D0\%BD\%D1\%96\%D0\%B2\%D0\%B5\%D1\%80\%D1\%81\%D0\%B8\%D1\%82 \%D0\%B5\%D1\%82 (Accessed: 19th June 2016).

The Russian Orthodox Church Official Website. (n.d.) Sayt "Russkaya Pravoslavnaya Tserkov'. Ofitsial'nyy sayt Moskovskogo Patriarkhata”. Opredelenie Osvyashchennogo Arkhiereyskogo Sobora Russkoy Pravoslavnoy Tserkvi ob obshchetserkovnom proslavlenii ryada mestnochtimykh svyatykh [The Official Website "The Russian Orthodox Church. The official website of the Moscow Patriarchate". The Resolution of the Consecrated Synod of Bishops of the Russian Orthodox Church about the Church-wide Glorification of Some Locally Venerated Saints]. [Online] Available from: http://www.patriarchia.ru/db/text/4367765.html (Accessed: 19th June 2016).

Anon. (1844) Pamyatniki dukhovnoy literatury vremeni velikogo knyazya Yaroslava I [Monuments of religious literature related to Grand Prince Yaroslav l's Rule]. Pribavlenie k tvoreniyam svyatykh ottsov $v$ russkom perevode. 2. pp. 204-317.

Pelevin, Yu. (2006) Boris i Gleb. Fakty i metafakty [Boris and Gleb. Facts and 
metafact]. Otechestvennye zapiski. 2(29). pp. 276-288.

Platonov, S.F. [1909] Uchebnik russkoy istorii dlya sredney shkoly. Kurs sistematicheskiy [The Textbook of Russian History for Secondary Schools. The systematic course]. St. Petersburg: M. Aleksandrov.

Grekov, B.D. (1947) Pravda russkaya [The Russian Truth]. Moscow; Leningrad: USSR Academy of Sciences.

Anon. (1853) Programmy russkogo yazyka na 1853-54 gg. [Programs of the Russian language in 1853-54]. St. Petersburg.

The Name of Russia. Historical choice 2008. (n.d.) Rezul'taty sotsiologicheskogo issledovaniya [The results of sociological research]. [Online] Available from: http://top50.nameofrussia.ru/doc.html?id=1647 (Accessed: 19th June 2016).

Rybakov, B.A. (1982) Kievskaya Rus'i russkie knyazhestva XII -XIII vV. [Kievan Rus and the Russian principalities in the 12th-13th centuries]. Moscow: Nauka.

Rybakov, B.A. (2003) Rozhdenie Rusi [The Birth of Rus]. Moscow: AlF Print.

Anon. (1823) Sinopsis ili kratkoe sobranie ot razlichnykh letopistsev o nachale slavyanorossiyskogo naroda [The synopsis or brief collection of various chroniclers of the birth of Slavs Russian people]. Kiev: [s.n.].

Sosnitskiy, D.A. (2010) Istoricheskaya pamyat' o dopetrovskoy Rusi v XIXnachale XXI v.: postanovka problemy i opyt issledovaniya [The historical memory of Rus before Peter the Great in the 19th - early 21st centuries: The problem and the experience of studies]. In: Dvornichenko, A.Yu. (ed.) Universitetskiy istorik [University Historian]. 7. St. Petersburg: St. Petersburg State University. pp. 423-430.

Sosnitskiy, D.A. (2015) Istoricheskaya pamyat'o dopetrovskoy Rusi v Rossii vtoroy poloviny XIX - nachala XXI vv. [The historical memory of Rus before Peter the Great in the late 19th - early 21st centuries]. History Cand. Diss. St. Petersburg.

Filist, G.M. (1990) Istoriya "prestupleniy" Svyatopolka Okayannogo [The history of Svyatopolk the Accursed's “crimes”]. Minsk: Belarus'.

Shchapov, Ya.N. (1984) Russkaya Pravda. Vvedenie [The Russian Truth. Introduction]. In: Chistyakov. O.I. (ed.) Rossiyskoe zakonodatel'stvo X-XX vekov [Russian legislation of the 10th - 20th centuries]. Moscow: Yuridicheskaya literatura.

Anon. (1931) Yaroslav I Vladimirovich [Yaroslav I]. In: Shmidth, O.Yu. (ed.) Bol'shaya sovetskaya entsiklopediya [Great Soviet Encyclopedia]. Vol. LXV. Moscow: Bol'shaya sovetskaya entsiklopediya. p. 25.

Anon. (1909) Yaroslav I Mudryy (1909) [Yaroslav I the Wise]. In: Brokhaus, B. \& Efron, I. (eds) Malyy entsiklopedicheskiy slovar' [The Brockhaus and Efron Encyclopedic Dictionary]. Vol. 2 (4). St. Petersburg: Brokaguz-Efron. 
Ростовцев Евгений Анатольевич - кандидат исторических наук, доцент кафедры истории России с древнейших времен до XX века Института истории Санкт-Петербургского государственного университета (Россия).

Rostovtsev Evgeniy - Saint Petersburg State University (Russia).

E-mail: e.rostovtsev@spbu.ru

Сосницкий Дмитрий Александрович - кандидат исторических наук, инженерпрограммист музейного комплекса Санкт-Петербургского государственного университета (Россия).

Sosnitsky Dmitry - Saint Petersburg State University (Russia).

E-mail: d.sosnitskij@spbu.ru 